\title{
Mediation Effect of Work Motivation on Relationship of Soft Skill and Hard Skill on Employee Performance in Denpasar Marthalia Skincare Clinical
}

\author{
Universitas Warmadewa, Denpasar-Bali, Indonesia \\ Email: bagusmarthalia@gmail.com
}

I Gusti Bagus Sindu Martha Nugraha, Ni Wayan Sitiari and Putu Ngurah Suyatna Yasa

\begin{tabular}{|l|}
\hline \multicolumn{1}{|c|}{ Published: 30/09/2021 } \\
\hline How to cite (in APA style): \\
Triwidyati, E., Pangastuti, R, L. (2021). Mediation Effect of Work Motivation on Relationship of Soft Skill and Hard Skill \\
on Employee Performance in Denpasar Marthalia Skincare Clinical. Jurnal Ekonomi dan Bisnis Jagaditha, 8(2), 136-145. \\
doi: https://doi.org/10.22225/jj.8.2.2021.136-145
\end{tabular}

\begin{abstract}
Employee motivation is a reflection of the level of energy, commitment, and creativity possessed by employees used to work. This study aims to determine the effect of soft skills and hard skills on employee performance with work motivation as a mediating variable in the Clinical Marthalia Skincare Denpasar. The population in this study were all employees who worked at Marthalia Skincare Clinic in 2019. The sampling method used in this study was the census method, thus, the number of samples in this study was 32 employees of the Marthalia Skincare Clinic in Denpasar. The research data is primary data that are the results of questionnaire data given to employees of the Marthalia Skincare Clinic Denpasar. Testing the hypothesis of this study using Structural Equation Modeling (SEM) analysis with the Partial Least Square (PLS) approach. The results showed that: (1) Soft Skill had a positive effect on work motivation. (2) Hard Skill has a positive effect on work motivation. (3) Soft Skill has a positive effect on employee performance. (4) Hard Skill has a positive effect on performance. (5) Work motivation has a positive effect on performance. (6) motivation is a partial mediation between soft skills and performance. (7) work motivation is not a mediation between hard skills and performance. It is recommended to further researchers to examine other mediating variables that affect the relationship between hard skills and employee performance.
\end{abstract}

Keywords: employee performance; hard skill; soft skill; work motivation

\section{INTRODUCTION}

Bali is a tourist destination in Indonesia which is visited by many foreign tourists. Beauty has become a lifestyle of people globally, not only in Indonesia but also in other countries. These conditions make beauty a necessity that must be met. This makes the business of skincare and body care grow rapidly.

The arrival of foreign tourists in Bali is an opportunity for these business people to be able to introduce skincare products and provide body care to people outside Indonesia at affordable prices. Beauty clinic as a business that is engaged in services makes HR is a very determining aspect of the performance of the beauty clinic.
Human resources have an important role in organizational activities because the progress and success of an organization cannot be separated from the role and ability of good resources. Human resources are actors in conducting business in organizations. Human resources are an important part of the organization. Organizational success is determined by employee decisions and behavior. This means that the performance of an organization is highly dependent on the performance of Human Resources. Thus, overall organizational performance is largely determined by employee performance.

Employee performance is influenced by various factors. Ability or skill is also stated as one of the factors that can affect employee performance. This is based on the concept that 
a job requires employees to draw from several different skills and abilities as well as from a variety of different knowledge. Various skills possessed by employees in a job can reduce boredom, thereby increasing job satisfaction and motivation (Kemboi, Biwott, Chenuos, \& Rutto, 2013). Ahmed et al. (2018) state that one's success in work is not only determined by hard skills such as learning achievement, technical skills, and general academic potential but is also influenced by soft skills, social skills, and emotional skills. The combination of hard skills and soft skills in the work environment will make employees able to make employees have good performance.

Mohamud et al. (2017) state that works motivation is also stated to affect employee performance. Employee motivation is as a process where the organization inspires employees with forms of awards, bonuses, etc. to achieve organizational goals. Motivation is a major factor influencing an organization's human resources. Through motivation, human resources can be utilized by making full use of it to build employees' willingness to work. These conditions assist companies in securing the best possible use of resources and resulting in increased productivity, reducing operating costs, and increasing overall efficiency (Shahzadi et al., 2014). Motivation encourages people to achieve organizational goals and objectives through every challenge and obstacle they face in the workplace; think of it as an advantage to move forward in the direction you have done for yourself (Omollo, 2015). Motivation can be measured based on salary increases, supervision, promotion, responsibility, training, and fringe benefits (Ghaffari et al., 2017).

The influence of motivation on employee performance has been reported by several researchers. Work motivation is stated to have a significant and positive effect on employee performance (Mohamud et al. (2017); Ali et al. (2016). However, other research states that intrinsic motivation does not affect employee performance (Muogbo, 2013).

The maximum attendance of employees at MSC clinics is expected to be able to develop skills both soft and hard skills so that later they can foster self-motivation in working and achieving good performance. Motivation is given as a driving force for employees to be able to mobilize abilities, expertise, skills, energy and time in doing work that is their responsibility and obligation, so that company goals can be achieved (Pratama, Musadieq, \& Nurtjahjono, 2017).
One of the beauty clinics in Bali is Marthalia Skincare (MSC). Marthalia Skincare offers a variety of body care services such as chemical peels, mesotherapy, facials, lasers, oxy skin, light therapy, full-blooded face, and body whitening. Supporting facilities such as a comfortable waiting room, air conditioning, television, and other facilities are also provided by the MSC clinic in the hope that consumers are satisfied in making care and purchasing products at the MSC clinic in Denpasar.

MSC Clinic in maintaining competition in addition to good human resource management also focuses on providing medical devices that are supported by modern technology that uses machines with advanced laser technology and offers a new concept of integrating aesthetics by providing anti-aging care, every service offered can prevent the aging process and can eliminate wrinkles on the face. The MSC beauty clinic offers aesthetic integration to customers who rely on the expertise of all staff ranging from receptionists, beauty therapists, pharmacists, nurses and a team of doctors who are experts in serving with abilities, skills and positive attitudes. Besides providing professional services and supported by modern equipment, MSC Clinic also offers all types of skincare at affordable prices.

Based on the phenomenon and gap research results of previous studies above, this study aims to determine the effect of soft skills and hard skills on employee performance with work motivation as a mediating variable at the Marthalia Skincare clinic in Denpasar.

\section{CONCEPT AND HYPOTHESIS}

\section{Effect of soft skills on work motivation}

Samosir et al. (2019) state that the competency in which one is measured by skill is stated to have a positive and significant effect on work motivation, the greater the competency given by the company to employees, the higher the employee motivation, and vice versa. Similar results were stated by Mamuaya \& Tumiwa (2019), Kurniawan et al. (2018), Heriyanto et al. (2018), and Murgianto et al. (2016). Gichure (2014) states that skills requirements and employee perceptions about skill development affects employee motivation. Intrinsic factors such as employee appreciation by the organization, the level of skill needs, the influence of employee views on work, employee perceptions about skills development, and perceptions about 
contributions to company growth are expressed as intrinsic factors that influence employee motivation. The skills required for employees to work consist of various types, one of which is soft skills. Based on the explanation that has been described, then the hypothesis can be taken namely:

H1: Soft skills have a significant and positive effect on employee work motivation.

\section{Effect of hard skills on work motivation}

Samosir et al. (2019) state that the competency in which one is measured by skill is stated to have a positive and significant effect on work motivation, the greater the competency given by the company to employees, the higher the employee motivation, and vice versa. Similar results were stated by Mamuaya \& Tumiwa (2019), Kurniawan et al. (2018), Heriyanto et al. (2018), and Murgianto et al. (2016). Gichure (2014) states that skills requirements and employee perceptions about skill development affects employee motivation. Intrinsic factors such as employee appreciation by the organization, the level of skill needs, the influence of employee views on work, employee perceptions about skills development, and perceptions about contributions to company growth are expressed as intrinsic factors that influence employee motivation. The skills required for employees to work consist of various types, one of which is hard skills. Based on the explanation that has been described, then the hypothesis can be taken namely:

H2: Hard skills have a significant and positive effect on employee work motivation.

\section{Effect of soft skills on employee performance}

Anggiani (2017) states that soft skills significantly affect employee performance and the coefficient value of soft skills is greater than hard skill variables. Individuals who have high emotional intelligence have better performance. Soft skills are behaviors that directly affect customer impressions and feelings. This behavior has the opportunity to cause positive, negative, or indifferent reactions. This behavior includes communication styles, both verbal and nonverbal, attitude, teamwork, awareness, authenticity, empathy, and even leadership. Soft skills show the side of personal service and how team members use their attitudes, behaviors, and verbal skills to interact with customers. The same thing was stated by Sitompul et al. (2017) that soft skills significantly affect the quality of one's work. Based on the explanation that has been described, then the hypothesis can be taken namely:

H3: Soft skills have a significant and positive effect on employee performance.

\section{Effect of hard skills on employee performance}

Hard skills include things like the system used to make reservations, procedures that are followed to check-in customers, processes that are followed to maintain the property, workflow preparing for banquets, and the like. Hard skills focus on the systems, tools, and methods used to provide products and services to customers. Hard skills are stated to significantly affect employee performance (Anggiani, 2017). The same thing was stated by Sitompul et al. (2017) that hard skills significantly affect the quality of one's work. Based on the explanation that has been described, then the hypothesis can be taken namely:

H4: Hard skills have a significant and positive effect on employee performance.

\section{The influence of work motivation on employee performance}

Motivation encourages people to achieve organizational goals and objectives through every challenge and obstacle they face in the workplace; think of it as an advantage to move forward in the direction you have done for yourself. The need for achievement always results in a desire to make extra efforts to do something better and has a desire for success. Managers must motivate employees to get things done without asking what to do. Extrinsic motivation, on the other hand, is resulted from the achievement of awards given externally including salary, materials, assets, prestige, and positive evaluations, among others (Omollo, 2015). Another opinion states that when employees realize that a view is considered valuable, it gives employees intelligence that can motivate employees. Incentives always meet the demands and requirements of workers and in return individuals pay for them through hard work and honesty (Ali et al., 2016). The results of research conducted by Ali et al. (2016) and Mohamud et al. (2017) states that work motivation has a significant and positive effect on employee performance. Based on the explanation that has been described, and then the hypothesis can be taken namely:

H5: Work motivation has a significant 
and positive effect on employee performance

The role of work motivation mediates the relationship between soft skills and employee performance

Mamuaya \& Tumiwa (2019) in their research stated that competencies (soft skills) affect employee performance directly and indirectly through motivation, and indirect effects through motivation are considered to have greater influence. Employees who have high skills, especially extensive knowledge, have high work motivation to work and make themselves able to do work better. Similar results were stated by Supriadi et al. (2018), Alexandri et al. (2019), Rijanti et al. (2017), Kurniawan et al. (2018) that work motivation can mediate the relationship between competence (soft skills) and employee performance. Based on the explanation that has been described, then the hypothesis can be taken namely:

H6: Work motivation mediates the relationship between soft skills and employee performance

The role of work motivation mediates the relationship between hard skills and employee performance

Rumasukun et al. (2015) in his study stated that hard skills affect employee performance directly and indirectly through motivation as a mediator or intervening variable. Employees who have competencies, namely abilities, hard skills, and high employee attitudes must be supported by high work motivation so that employee performance is increasing. High employee motivation can improve employee performance. Work motivation can affect work attitudes and work performance. Similar results were stated by Haluk et al. (2016), Supriadi et al. (2018), Utoyo et al. (2019), Wetipo et al. (2015) that work motivation mediates the relationship between competence (hard skills) and employee performance. Based on the explanation that has been described, and then the hypothesis can be taken namely:

H7: Work motivation mediates the relationship between hard skills and employee performance .

\section{METHOD}

The population in this study was all employees who worked at Marthalia Skincare Clinic in 2019. The sampling method used in this study was the census method, thus, the number of samples in this study was 32 employees of the Marthalia Skincare Clinic in Denpasar. The research data is primary data that are the results of questionnaire data given to employees of the Marthalia Skincare Clinic Denpasar. Testing the hypothesis of this study used Structural Equation Modeling (SEM) analysis with the Partial Least Square (PLS) approach.

\section{RESULT AND DISCUSSION}

\section{Evaluasi Model Pengukuran (Measurement Model/Outer Model)}

In connection with the indicators that form latent variables in this study are reflexive, the evaluation of measurement models, to measure the validity and reliability of these indicators are a) convergent validity, b) discriminant validity, and c) composite reliability and Cronbach alpha. The measurement model is used because the indicators that form latent variables in this study are reflexive.

\section{Convergent Validity}

Convergent validity is done through an examination of the outer loading coefficient of each indicator of its latent variable. An indicator is said to be valid if the coefficient of outer loading is between $0.60-0.70$, but for analyzes where the theory is unclear, 0.50 outer loading is recommended (Ghozali \& Lathan, 2012:78), and is significant at alpha level 0.05 or t-statistics 1.96 . All outer loading indicators have values $>0.50$ so they are said to meet the requirements of discriminant validity measurements.

Table 1. Outer Loading Values

\begin{tabular}{lll}
\hline Indicator <-construct & $\begin{array}{l}\text { Origina } \\
\text { I }\end{array}$ & $\begin{array}{l}\text { T } \\
\text { Statistic } \\
\text { Sample }\end{array}$ \\
\hline x1.1<- soft skill & 0,81 & 13,54 \\
x1.2<- soft skill & 0,68 & 8,81 \\
x1.3<- soft skill & 0,64 & 7,16 \\
x1.4<- soft skill & 0,64 & 5,92 \\
x1.5<- soft skill & 0,79 & 10,98 \\
x2.1<- hard skill & 0,87 & 13,29 \\
x2.2<- hard skill & 0,60 & 7,14 \\
x2.3<- hard skill & 0,60 & 6,54 \\
x2.4<- hard skill & 0,87 & 13,47 \\
x2.5<- hard skill & 0,67 & 7,90 \\
y12<- work motivation & 0,55 & 8,92 \\
y13<- work motivation & 0,60 & 9,61 \\
y14<- work motivation & 0,76 & 15,08 \\
y16<- work motivation & 0,57 & 8,91 \\
y17<- work motivation & 0,53 & 7,24 \\
y18<- work motivation & 0,73 & 13,10 \\
y21<- performance & 0,70 & 13,30 \\
y22 <- performance & 0,70 & 12,79 \\
y24 <- performance & 0,55 & 9,76 \\
y25 <- performance & 0,70 & 6,88 \\
y26<- performance & 0,58 & 8,13 \\
\hline
\end{tabular}




\section{Discriminant Validity}

The measurement of the validity of the indicators that make up the latent variable can also be done through discriminant validity by looking at the value of AVE and AVE. Indicators are considered valid if the AVE value of each construct is $>0.50$ and the value of AVE is all constructs $>$ the correlation value between variables (Ghozali \& Lathan, 2012:78-79). Indicators are considered valid if the AVE value of each construct is $>0.50$ and the value of AVE is all constructs $>$ the correlation value between variables (Ghozali \& Lathan, 2012:78-79).

Table 2. Discriminant Validity

\begin{tabular}{ccccccc}
\hline construct & AVE & $\sqrt{ }$ AVE & Hard skill & Performance & $\begin{array}{c}\text { Work } \\
\text { motivation }\end{array}$ & $\begin{array}{c}\text { Soft } \\
\text { skill }\end{array}$ \\
\hline Hard skill & 0,54 & 0,73 & 1,00 & & & \\
Employee performance & 0,52 & 0,72 & 0,68 & 1,00 & & \\
Work motivation & 0,60 & 0,77 & 0,66 & 0,62 & 1,00 & \\
Soft skill & 0,51 & 0,71 & 0,51 & 0,75 & 0,59 & 1,00 \\
\hline
\end{tabular}

\section{Composite Reliability and Cronbach Alpha}

A measurement can be said to be reliable if the composite reliability and Cronbach alpha have a value greater than 0.70 . Composite reliability and Cronbach alpha is a measure of reliability among indicator blocks in the research model.

Table 3. Composite Reliability and Cronbach Alpha

\begin{tabular}{ccc}
\hline Construct & $\begin{array}{c}\text { Composite } \\
\text { reliability }\end{array}$ & $\begin{array}{c}\text { Cronbach's } \\
\text { alpha }\end{array}$ \\
\hline Hard skill & 0,85 & 0,88 \\
Employee & 0,78 & 0,88 \\
performance & 0,79 & 0,91 \\
Work motivation & 0,84 & 0,86 \\
Soft skill &
\end{tabular}

Table 3 shows that the composite reliability value of each construct shows a value greater than 0.70 . In terms of Cronbach Alpha values, all constructs have index values greater than 0.70. Evaluation of Structural Model / Inner Model Evaluation of this structural model will be carried out through several approaches including a) R-Square $\left(\mathrm{R}^{2}\right)$, b) Q-Square Predictive Relevance $\left(Q^{2}\right)$, and c) Goodness of Fit (GoF).

a). Evaluation of Structural Models through R-Square $\left(\mathrm{R}^{2}\right)$

R-Square $\left(R^{2}\right)$ can also show the strengths and weaknesses of a research model. According to Chin (Ghozali \& Lathan, 2012:85), an R-Square $\left(\mathrm{R}^{2}\right)$ value of 0.67 is classified as a strong model, R-Square $\left(\mathrm{R}^{2}\right)$ of 0.33 moderate model, and $\mathrm{R}$-Square $\left(\mathrm{R}^{2}\right)$ of 0 , 19 is classified as a weak model.
Table 4. Evaluation of the Inner Structural Model

\begin{tabular}{cc}
\hline Construct & R square \\
\hline Hard skill & \\
Employee & 0,79 \\
performance & 0,52 \\
Work motivation & \\
Soft skill & \\
\hline
\end{tabular}

Table 4 shows that the R2 performance value is 0.79 ; based on Chin criteria (Ghozali \& Lathan, 2012:85), then the model is included in the strong model criteria, the meaning is a variation of hard skills, soft skills, and work motivation can explain variations in performance by $79 \%$ percent, the remaining $21 \%$ percent is explained by variations of other variables outside the analyzed model. While work motivation has an $\mathrm{R}$-square value of 0.52 or includes a strong model, meaning that the variation of hard skills and soft skills can explain the variation of motivation that is equal to $52 \%$ percent while the remaining $48 \%$ is explained by other variables outside the model.

2) Evaluation of Structural Models through Q-Square Predictive Relevance (Q2)

Criteria for strength or weakness of the model are measured based on Q-Square Predictive Relevance $\left(\mathrm{Q}^{2}\right)$ according to Ghozali \& Lathan (2012:85) are as follows: 0.35 (strong model), 0.15 (moderate model), and 0.02 (weak model ). The Q-Square formula is $\mathrm{Q}^{2}=1-(1-\mathrm{R} 12)(1-\mathrm{R} 22)$.

The value of Q-Square is $=1-(1-\mathrm{R} 12)(1$ $-\mathrm{R} 22)=1-(1-0.79)(1-0.52)=1-0.10=$ 0.90 , based on this result then the estimation model is included in the strong criteria, meaning that $90 \%$ of variations in endogenous constructs can be predicted by variations in 
exogenous constructs.

3) Evaluation of Structural Models through Goodness of Fit (GoF)

Table 5. Evaluation of Goodness Of Fit

\begin{tabular}{ccc}
\hline Construct & R square & Communality \\
\hline Hard skill & & 0,95 \\
Employee & 0,79 & 0,97 \\
performance & 0,52 & 0,96 \\
Work motivation & & 0,97 \\
Soft skill & & 0,96 \\
Soft skill & 0,66 &
\end{tabular}

The criteria for strength and weakness of the model based on the measurement of Goodness of Fit (GoF) according to Ghozali \& Lathan (2012:88), are as follows: 0.36 (GoF large), 0.25 (GoF medium), and 0.10 (GoF small). (Tenenhaus et al., 2004: 175).

Calculation with GoF shows an average value of R2 of 0.89 while an average of Communality of 0.96 , then a GoF value of $\sqrt{ }$ AR2 $*$ A.Com/A.rho $=\sqrt{ } 0.66 * 0.96=\sqrt{ } 0,63$ $=0,79$ This means that the global model is a large predictive.

2) Path Analysis and Testing Hypotheses, it is expected that Ho is rejected or sig $<0.05$ (or t-statistic value $>1.96$ with a level of significance of 0.05).

The results of the significance test (bootstrapping) before reconstruction can be seen in Figure 2.

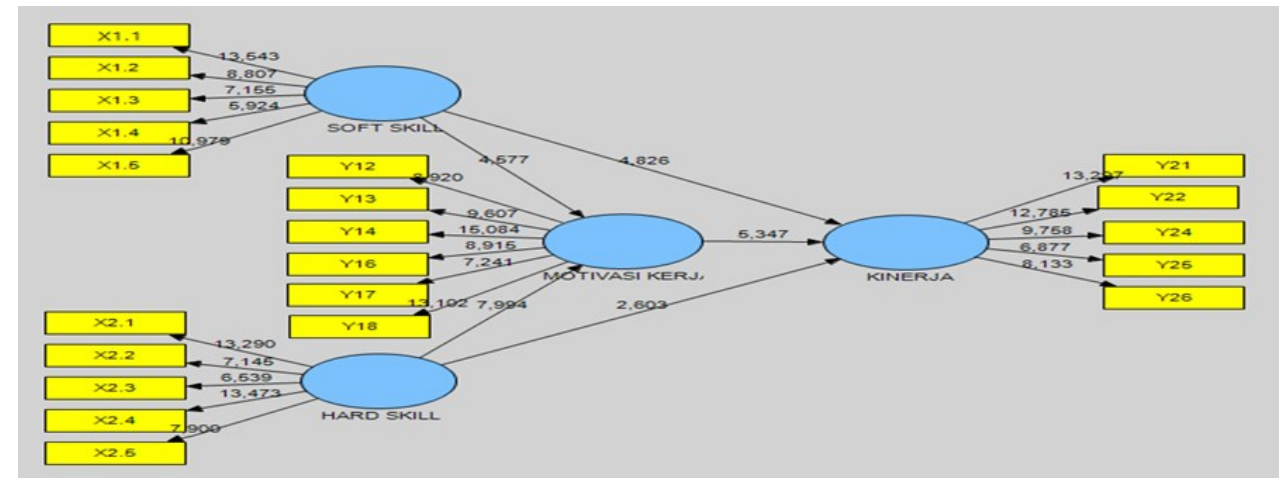

Figure 2. SEM PLS Calculation

Table 6. Path Analysis and Testing Statistics

\begin{tabular}{cccccc}
\hline Construct & $\begin{array}{c}\text { Original } \\
\text { sample } \\
\mathbf{( o )}\end{array}$ & $\begin{array}{c}\text { Sample } \\
\text { mean } \\
\mathbf{( m )}\end{array}$ & $\begin{array}{c}\text { Standard } \\
\text { deviation } \\
\text { (stdev) }\end{array}$ & $\begin{array}{c}\text { Standar } \\
\text { d error } \\
\text { (sterr) }\end{array}$ & $\begin{array}{c}\text { T } \\
\text { statistics } \\
(|\mathbf{o} / \mathbf{s t e r}| \mathbf{)}\end{array}$ \\
\hline Hard skill -> performance & 0,17 & 0,17 & 0,07 & 0,07 & 2,60 \\
Hard skill -> work motivation & 0,48 & 0,49 & 0,06 & 0,06 & 7,99 \\
Work motivation -> performance & 0,48 & 0,48 & 0,09 & 0,09 & 5,35 \\
Soft skill -> performance & 0,37 & 0,38 & 0,08 & 0,08 & 4,83 \\
Soft skill -> work motivation & 0,34 & 0,33 & 0,07 & 0,07 & 4,58 \\
\hline
\end{tabular}

The results show that Soft Skill has a positive effect on work motivation by 0.34 and is statistically significant with a calculated value of 4.58 greater than the t table value of 1.96. Hard Skill has a positive effect on motivation by 0.48 , and the relationship is significant at the 0.05 level with a $t$ value of 7.99. Soft Skill has a positive effect on employee performance by 0.37 and significant at the 0.05 level with a calculated value of 4.83 is greater than the $\mathrm{T}$ value of table 1.96. Hard Skill has a positive effect of 0.17 on performance, and the relationship is significant at the 0.05 level because the T-Statistic value is greater than 1.96 which is equal to 2.60 . Work motivation has a positive effect of 0.48 on performance, and the relationship is significant at the 0.05 level with a $t$ value of 5.35 greater than the T-table value of 1.96 . Motivation is a partial mediation between soft skills and performance. The results show that work motivation is not a mediation between hard skills and performance.

\section{DISCUSSION}




\section{Effect of Soft Skill on Work Motivation}

Soft skills have a significant positive effect on employee motivation at the MSC Clinic in Denpasar. Increased soft skills of MSC Clinic employees can increase employee motivation. The results of this study are in line with the results of research conducted by Samosir et al. (2019) competency, one of which is measured by skill, is stated to have a positive and significant effect on work motivation, the greater the competence given by the company to employees, the higher the employee motivation, and vice versa. Similar results were stated by Mamuaya \& Tumiwa (2019), Kurniawan et al. (2018), Heriyanto et al. (2018), and Murgianto et al. (2016). Gichure (2014) states that skills requirements and employee perceptions about skill development affect employee motivation. Intrinsic factors such as employee appreciation by the organization, the level of skill needs, the influence of employee views on work, employee perceptions about skills development, and perceptions about contributions to company growth are expressed as intrinsic factors that influence employee motivation. The skills required for employees to work consist of various types, one of which is soft skills.

\section{Effects of Hard Skills on Work Motivation}

Hard skills have a significant positive effect on employee work motivation at the MSC Clinic in Denpasar. Increased hard skills of MSC Clinic employees can increase employee motivation. The results of this study are in line with the results of research conducted by Samosir et al. (2019) competency, one of which is measured by skill, is stated to have a positive and significant effect on work motivation, the greater the competence given by the company to employees, the higher the employee motivation, and vice versa. Similar results were stated by Mamuaya \& Tumiwa (2019), Kurniawan et al. (2018), Heriyanto et al. (2018), and Murgianto et al. (2016). Gichure (2014) states that skills requirements and employee perceptions about skill development affect employee motivation. Intrinsic factors such as employee appreciation by the organization, the level of skill needs, the influence of employee views on work, employee perceptions about skills development, and perceptions about contributions to company growth are expressed as intrinsic factors that influence employee motivation. The skills required for employees to work consist of various types, one of which is a hard skill.

\section{Effect of Soft Skill on Employee Performance}

Soft skills have a significant positive effect on employee performance at the MSC Denpasar Clinic. Increased soft skills of MSC Beauty Clinic employees can improve employee performance. The results of this study are in line with the results of research conducted by Anggiani (2017) which states that soft skills significantly affect employee performance and the coefficient value of soft skills is greater than the hard skill variable. Individuals who have high emotional intelligence have better performance. Soft skills are behaviors that directly affect customer impressions and feelings. This behavior has the opportunity to cause positive, negative, or indifferent reactions. This behavior includes communication styles, both verbal and non-verbal, attitude, teamwork, awareness, authenticity, empathy, and even leadership. Soft skills show the side of personal service and how team members use their attitudes, behaviors, and verbal skills to interact with customers. The same thing was stated by Sitompul et al. (2017) that soft skills significantly affect the quality of one's work

\section{Effect of Hard Skills on Employee Performance}

Hard skills have a significant positive effect on employee performance at the MSC Denpasar Clinic. Increased hard skills of MSC Clinic employees can improve employee performance. The results of this study are in line with the results of research conducted by Cimatti, (2016) which proves that hard skills significantly affect employee performance. Hard skills consist of systems and processes established to provide services and facilities to customers. Hard skills include things like the system used to make reservations, procedures that are followed to check-in customers, processes that are followed to maintain the property, workflow preparing for banquets, and the like. Hard skills focus on the systems, tools, and methods used to provide products and services to customers. Hard skills are stated to significantly affect employee performance (Anggiani, 2017). The same thing was stated by Sitompul et al. (2017) that hard skills significantly affect the quality of one's work.

Effect of Work Motivation on Employee Performance

Based on the results of hypothesis testing 
that work motivation has a significant positive effect on employee performance at the Denpasar MSC Clinic. Thus the hypothesis in this study which states that work motivation has a positive effect on employee performance at the MSC Clinic has been tested for truth. This means that increasing the work motivation of MSC Clinic employees can improve employee performance. The results of this study are in line with the results of research conducted by Ali et al. (2016) and Mohamud et al. (2017) state that work motivation has a significant and positive effect on employee performance. This result is reinforced by Omollo (2015) that there is a positive and significant effect between work motivation and employee performance. This can be interpreted that the better work motivation that occurs in a company will result in increased employee performance.

\section{The role of work motivation mediates the relationship between soft skills and employee performance}

Motivation is a partial mediation between soft skills and employee performance. These results are in line with research conducted by Supriadi et al. (2018), Alexandri et al. (2019), Rijanti et al. (2017), Kurniawan et al. (2018) that work motivation can mediate the relationship between competence and employee performance. Mamuaya \& Tumiwa (2019) in their research stated that competence influences employee performance directly and indirectly through motivation, and indirect influence through motivation is considered to have greater influence. Employees who have high competence and skills, especially extensive knowledge, have high work motivation to work and make themselves able to do work better.

The role of work motivation mediates the relationship between hard skills and employee performance

Motivation is not a mediation between hard skills and employee performance. These results are not in line with research conducted by Rumasukun et al. (2015) in his research stated that competence directly affects employee performance and indirectly through motivation as a mediator or intervening variable. Employees who have competencies, namely abilities, hard skills, and high employee attitudes must be supported by high work motivation so that employee performance is increasing. High employee motivation can improve employee performance. Work motivation can affect work attitudes and work performance. Similar results were stated by Haluk et al. (2016), Supriadi et al. (2018), Utoyo et al. (2019), Wetipo et al. (2015) that work motivation mediates the relationship between hard skill competencies and employee performance. The difference in the results obtained in this study is due to MSC clinic employees in carrying out work serving patients using the skills and abilities possessed by their respective scientific implications professionally in carrying out their duties and responsibilities.

\section{CONCLUSION}

Based on the results and discussion explained above, it can be concluded that the better soft skills possessed by an employee, the better the work motivation of employees of the Marthalia Skincare Clinic Denpasar. The better the hard skills possessed by an employee, the better the work motivation of the employees of Marthalia Skincare Beauty Clinic Denpasar. Good soft skills possessed by employees can improve employee performance at the Marthalia Skincare Clinic in Denpasar. The ability of good hard skills possessed by employees can provide improved employee performance at the Denpasar Marthalia Skincare Clinic. Good work motivation possessed by employees can provide improved employee performance at Marthalia Skincare Clinic Denpasar. Work motivation is not a mediation between hard skills and employee performance.

\section{REFERENCES}

Ahmed, S. M., Madhuri, G., Reddy, M. S., \& Condoor, S. S. (2018). Skill Development in Freshmen by Adopting Project Based Learning-"Introduction to Engineering" Cour. Ournal of Engineering Education Transformations, 2(6), 1-6. https:// doi.org/10.16920/jeet/2018/v0i0/120886

Alexandri, M. B., Pragiwani, M., \& Yuswardi. (2019). The Effect of Competence and Discipline of Work on Motivation and its Impact on Performance of Forensic Checkers at Puslabfor Bareskrim Indonesia National Police (POLRI). Academy of Strategic Management Journal, 18(4). Retrieved from https:// www.abacademies.org/abstract/the-effect-of -competence-and-discipline-of-work-onmotivation-and-its-impact-on-performanceof-forensic-checkers-at-pusl-8320.html

Ali, A., Bin, L. Z., Piang, H. J., \& Ali, Z. (2016). The Impact of Motivation on the Employee Performance and Job Satisfaction in IT Park (Software House) Sector of Peshawar, Pakistan. International Journal of Academic 
Research in Business and Social Sciences, 6 (9), 297-310. Retrieved from https:// ideas.repec.org/a/hur/ijarbs/v6y2016i9p297310.html

Anggiani, S. (2017). Skill Influence on Employee Performance (Empirical Study of Frontlines three Star Hotels in Jakarta). International Journal of Management and Applied Science (IJMAS), 3(12), 14-18. Retrieved from http://ijmas.iraj.in/paper_detail.php? paper_id=10413\&name=Skill_Influence_on Employee Performance

(Empirical_Study_of_Frontlines_three_Star Hotels_in_Jakarta)

Ghozali, \& Lathan, H. (2012). Partial Least Square "Konsep Metode dan Aplikasi" Menggunakan Program WarpPLS 2.0. Semarang: Badan Penerbit Universitas Diponegoro.

Gichure, C. N. (2014). Factors Influencing Employee Motivation and its Impact on Employee Performance: A Case of Amref Health Africa in Kenya. United States International University, Africa.

Haluk, R., Rante, Y., Risamasu, F., \& Syauta, J. H. (2016). The Mediation Effect of Work Motivation in Relationship Between Employee Competencies, Leadership, Education and Training Toward Employee Performance (Case Study on Social And Settlement in Papua Province). International Journal of Business Management, 2(2), 4052. Retrieved from www.sciarena.com

Heriyanto, T., Naser, J. A., \& Setia, K. A. (2018). The Effect of Competence and Discipline on Work Motivation and Impact on Employee Performance of Pratama Tax Office in Malang Utara. Management and Economic Journal (MEC-J), 2(3), 269-278. https:// doi.org/10.18860/mec-j.v0i0.5872

Kemboi, A., Biwott, G., Chenuos, N. K., \& Rutto, A. (2013). Skill Variety, Feedback and Employee Performance: A Case of Moi Teaching and Referral Hospital Eldoret. European Journal of Business and Management, 5(19), 151-155. Retrieved from https://iiste.org/Journals/index.php/ EJBM/article/view/7284

Kurniawan, A., Rivai, A., \& Suharto. (2018). Effect of Employee Placements and Competency on Employee Performance through Motivation in Pt. Bank Capital Indonesia TBK Branch of Kuningan Tower Jakarta. Scholars Journal of Economics, Business and Management (SJEBM), 5(2), 126-135. https://doi.org/10.21276/sjebm.2018.5.2.6

Mamuaya, N. C. I., \& Tumiwa, R. A. (2019). Determinants of Motivation and Its Implications Toward the Performance of Lecturers at Private Colleges in Manado. KnE Social Sciences, 3(11), 794. https:// doi.org/10.18502/kss.v3i11.4051

Mohamud, S. A., Ibrahim, A. A., \& Hussein, J. M.
(2017). The Effect of Motivation on Employee Performance: Case study in Hormuud Company in Mogadishu Somalia. International Journal of Development Research, 9(11), 17009-17016.

Muogbo, U. (2013). The Influence of Motivation on Employees' Performance: A Study of Some Selected Firms in Anambra State. AFRREV IJAH: An International Journal of Arts and Humanities, 2(3). Retrieved from https://www.ajol.info/index.php/ijah/article/ view/106475

Murgianto, Sulasmi, S., \& Suhermin. (2016). The Effects of Commitment, Competence, Work Satisfaction on Motivation, and Performance of Employees at Integrated Service Office of East Java. International Journal of Advanced Research (IJAR), 3(3), 378-396. Retrieved from https://www.journalijar.com/ article/8021/the-effects-of-commitment,competence,-work-satisfaction--onmotivation,-and-performance-of-employeesat-integrated-service-office-of-east-java/

Pratama, M. R. B., Musadieq, M. Al, \& Nurtjahjono, G. E. (2017). Pengaruh Motivasi Kerja dan Kepuasan Kerja terhadap Kinerja Karyawan (Studi pada Karyawan Giant Hypermarket Mall Olympic Garden Malang). Jurnal Administrasi Bisnis, 47(1). Retrieved from http:// administrasibisnis.studentjournal.ub.ac.id/ index.php/jab/article/view/1815

Rijanti, T., Priyono, B. S., \& Nugroho, H. P. (2017). The Influence of Competence and Job Characteristics on Performance with Motivation as Mediating Variable at Regional Finance Agency of Tegal City. The Sixth International Conference on Enterpreunership and Business Management. Retrieved from https:// www.unisbank.ac.id/ojs/index.php/fe10/ article/view/5592

Rumasukun, S. F. A., Rante, Y., Wambrauw, O. O., \& Bharant, B. E. (2015). The Influence of Human Resource Management Strategy and Competence on Employee Performance with the Mediation of Work Motivation, Organizational Commitment and Work Culture (Study at the Official of Management of Communication and Information Technology o. International Journal of Business and Management Invention, 4(8), 15-27. Retrieved from https://www.ijbmi.org/papers/Vol(4)8/ C0408015027.pdf

Samosir, D. P., Aima, M. H., \& Markum. (2019). The Effect of Work Spirit and Competence on Work Motivation and its Implementation on Employee Productivity of Factory PT. Sinar Metrindo Perkasa. International Journal of Innovative Science and Research Technology, 4(5). Retrieved from https:// ijisrt.com/the-effect-of-work-spirit-andcompetence-on-work-motivation-and-its- 
implementation-on-employee-productivityof-factory-pt-sinar-metrindo-perkasa

Shahzadi, I., Javed, A., Pirzada, S. S., Nasreen, S., \& Khanam, F. (2014). Impact of Employee Motivation on Employee Performance. European Journal of Business and Management, 6(23). Retrieved from https:// iiste.org/Journals/index.php/EJBM/article/ view/14794

Sitompul, S. S., Kustono, D., Suhartadi, S., \& Setyaningsih, R. M. (2017). The Relationship of the Learning of Tourism Marketing, Hard Skills, Soft Skills and Working Quality of the Graduates of Tourism Academy in Medan. International Journal of Social Sciences \& Educational Studies, 3(4). https://doi.org/10.23918/ ijsses.v3i4p 124

Supriadi, A. D., Suharto, S., \& Sodikin, S. (2018). The Effect of Competence and Organization Culture to Employee Performance with Motivation as the Mediation Variable in the Directorate General of Fiscal BalanceMinistry of Finance, Indonesia. Jurnal Perspektif Pembiayaan Dan Pembangunan Daerah, 5(4), 325-336. https:// doi.org/10.22437/ppd.v5i4.4606

Utoyo, B., Yohana, C., \& Mardi. (2019). The Effect of Competence and Organizational Culture, on Performance of Employees with Work Motivation as a Mediation Variable. Retrieved from Research Gate website: https://www.researchgate.net/ publication/333078287_THE_EFFECT_OF COMPETENCE AND ORĞANIZAT̄ION $\bar{A} L$ CULTURE ONN PERFORMANCE O F EMPLOYEES WITH WORK MOTIVV ATION_AS_A_MEDIAT̄ION_VĀRIABLE

Wetipo, W., Rante, Y., Wambraw, O., \& Bharanti, E. (2015). The Mediating Effect of Job Satisfaction and Job motivation to Influence School Leadership, Teacher Competence and Experience of Teachers on Performance of Teachers in SMA/SMK in Jayawijaya, Indonesia. Journal of Resources Development and Management, 15, 10-16. Retrieved from https:// www.semanticscholar.org/paper/TheMediating-Effect-of-Job-Satisfaction-andJob-to-Wetipo-Rante/ c87fabcf71c79d134e749c3b361fcf9bflce5e 51 